\title{
KAKLO ATPALAIDAVIMO IR AKIŲ MANKŠTOS POVEIKIS REGËJIMUI
}

\author{
Tomas Miklius ${ }^{1}$, Artūras Razbadauskas ${ }^{2,1}$, Jūratė Sučylaitė ${ }^{1}$ \\ ${ }^{1}$ Klaipédos universitetas, ${ }^{2}$ Klaipédos jūrininku ligoninè
}

Raktažodžiai: kaklinè stuburo dalis, postizometrinė relaksacija, toliaregiai, trumparegiai, regèjimo aštrumas, akių pratimai.

\begin{abstract}
Santrauka
Tyrimas atliktas $2016 \mathrm{~m}$. sausio - balandžio mėnesiais. Tyrime dalyvavo 90 atrinktų asmenų, turinčių toliaregystę (45 asmenys) ir trumparegystę (45 asmenys). Tiriamujų atrankos ir regejjimo atstatymo programos efektyvumo vertinimo tikslais naudotos regejimo aštrumo vertinimo (Sneleno) ir teksto skaitymo lentelès. Jei, vertinant Sneleno lentele, regos aštrumas buvo mažesnis už 1,0 , buvo nustatomas trumparegystès sutrikimas. Jei teksto skaitymo lentelèje perskaitomas šriftas buvo didesnis už 12, buvo nustatomas toliaregystès sutrikimas. Visi tiriamieji buvo suskirstyti $i$ tris grupes. I grupès tiriamieji: trumparegiai $(n=15)$ ir toliaregiai $(n=15)-10$ dienų atliko akių pratimus, II grupès tiriamiesiems: trumparegiams $(n=15)$ ir toliaregiams $(n=15)-10$ dienų taikyta postizometriné relaksacija, III grupés tiriamiesiems: trumparegiams $(n=15)$ ir toliaregiams $(n=15)$ - 10 dienų taikyta postizometriné relaksacija kartu su akių pratimais. Regejjimo atstatymo programa taikyta kasdien, iš viso 10 dienų. Taikytas statistinis duomenų apdorojimas. Tyrimas atliktas laikantis etikos principų. Tyrimo rezultatai parode, kad toliaregiu ir trumparegių rega pagerèjo, taikant visas metodikas. Atliekant postizometrinę relaksaciją kartu su akių pratimais, toliaregiu ir trumparegiu grupėse statistiškai reikšmingai pagerejo regejjimas. Kaklo ir pečių juostos postizometrinè relaksacija efektyviai gerina trumparegiu regejimą. Postizometrinès relaksacijos kartu su akių pratimais ir atskirai postizometrinès relaksacijos poveikis regejjimui statistiškai nesiskiria $(\mathrm{p}=0.589$, $\mathrm{p}>0.05$ ). Akių pratimai turèjo teigiamą, bet statistiškai nereikšmingą poveikị toliaregių ir trumparegių regejjimui $(\mathrm{p}>0,05)$.
\end{abstract}

\section{Ivadas}

Pastaraisiais metais tradicišką mąstymą, kad dauguma akių ligų yra susijusios su senejjimu, keičia kitas požiūris: galvojama, kad akių sistemos sutrikimus gali sukelti akių raumenų įtampa arba silpnumas, kaklo srities slankstelių ir raumenų pokyčiai, trigeriniai taškai, stresas ir mityba [1]. Ilgai sėdint, kaupiasi įtampa viršutinèje kūno dalyje - pečiuose, kakle, galvoje, todèl pasunkèja kvėpavimas, organizmas negauna reikiamo kiekio energijos, akys ir smegenys - deguonies [2]. Viena pagrindinè prasto regèjimo priežasčių - problemos susijusios su laikysena, ypač su įtampa viršutinèje kūno dalyje - pečiuose, kakle [3]. Blogèjant kaklo kraujotakai, per ilgą laiką suprasteja akies kraujotaka ir mityba - tai yra viena akies nuovargio ir regejjimo sutrikimų priežasčių.[4]. Akies skersiniams raumenims dèl perkrovų pradejjus spazmuoti, atsiranda didelè raumenų itampa, jie nebegali visiškai atsipalaiduoti, akies obuolys tampa pailgas, o žmonės - trumparegiais: jie nebegali aiškiai matyti ị toli [5]. Dél pakitusios kaklinès stuburo dalies linkio, gali pakisti žiūros kampas, atsirasti akių nuovargis [6], o vẻliau, trumparegystè. Dẻl pakitimų kaklo srityje, gali kartotis migrena, pablogèti regèjimas, klausa [7].

Trigeriniai taškai, susidarantys bet kurioje žmogaus kūno minkštojo audinio vietoje, miofascijiniai trigeriniai taškai, susidarantys fascijoje arba raumenyje, nustatomi 27,5 - 50 metu amžiaus žmonèms, kurie daugiausia dirba sèdimą darbą, dažniau moterims. Miofascijiniai trigeriniai taškai gali užspausti net nervines šakneles, pažeisti nervą ir sukelti jo sutrikimų. Tarp antrojo ir trečiojo kaklo slankstelių (C2 ir C3) yra pagrindinè pablogejjusio regejjimo priežastis - užspausti akis valdantieji nervai. Tai viena iš toliaregystès atsiradimo priežasčių [8].

Raumenų atpalaidavimas duoda naudos ne tik gydant raumenu itampas, tačiau kartu padeda atstatyti psichologinę pusiausvyrą, o juk tai pagrindas geram matymui [9], atpalaidavus raumenis, palengvejja ir pagerejja regos organų aprūpinimas deguonimi ir maisto medžiagomis [3], mankštinant akių raumenis, kartu veikiamos ir smegenys, todèl 
šių pratimų svarba didžiulė [10]. Derinant akių mankštą su kaklo masažu, galima greičiau ir efektyviau pasiekti teigiamų regèjimo pokyčių [4]. Šiuolaikinès manualinès terapijos vienas iš atlikimo technikos tipų yra postizometrinès relaksacijos metodas, naudojantis raumenų energiją [11]. Postizometrinė relaksacinè technika yra naudojama norint sumažinti raumenų ịtampą bei greta esančių sąnarių disfunkciją pacientams, turintiems miofascijini skausmo sindromą [12].

Nepaisant daugybės empirinių duomenų, liudijančių teigiamą akių mankštos poveikị regejjimui, vis dar nèra mokslinių įrodymų, kad akių pratimai yra efektyvi regèjimo gerinimo priemonè. Atskirais atvejais aptiktas regejjimo pagerejjimas išliko ilgesnị laiką, patvirtintas per pakartotinį regejimo patikrinimą, vis dèlto šie rezultatai nebuvo pripažinti kaip miopijos išgydymas, o aprašyti tik atskiri aspektai [13]. Naujojoje Zelandijoje, îvertinus 43 tyrimų, skirtų akių pratimų apžvalgai, rezultatus, teigta, kad iki šiol nèra aiškių mokslinių irodymų, kurie palaikytų akių pratimų taikymą [14].

Išanalizavę laikysenos ir akių raumenų įtampos poveikio regejjimui teorinius aspektus ir mums žinomą empirinių tyrimų medžiagą, darome prielaidą, kad šalinant akių raumenų silpnumą, ịtampą, galima būtų užkirsti kelią regejjimo prastejjimui, tačiau ši problema yra per mažai moksliškai analizuota, trūksta išsamesnių raumenų ịtampos šalinimo būdų poveikio regejjimui tyrimų.

Tyrimo tikslas: ịvertinti postizometrinès relaksacijos ir akių mankštos poveikị regèjimui.

\section{Tyrimo metodika}

Tyrimas atliktas $2016 \mathrm{~m}$. sausio - balandžio mėnesiais X Kretingos rajono ligonineje. Tyrime dalyvavo 90 tiriamujų (37 vyrai ir 53 moterys), kurių amžius nuo 21 iki 64 metų. Tyrimo dalyvių atranka buvo vykdoma vadovaujantis šiais kriterijais: tiriamujų amžius nuo 18 iki 65 metų; regejjimo sutrikimas - toliaregyste ir trumparegyste. Regos aštrumas buvo tikrintas be akinių. Trumparegiu regos aštrumas buvo nustatomas, tiriant atskirai kiekvieną akị ir abi kartu, naudojantis Sneleno lentele. Testavimas buvo registruojamas matomos eilutès užfiksavimu. Normalus regos aštrumas yra 1,0 (dešimtoji lentelès eilutè). Jei regos aštrumas buvo mažesnis už 1,0 , buvo nustatomas trumparegystès sutrikimas.

Toliaregiu teksto skaitymą vertinome, tirdami atskirai kiekvieną akį ir abi kartu, naudodamiesi Tomo Mikliaus sugalvota teksto skaitymo lentele, kurios eilutėse pateiktas tekstas su didejančiu iš viršaus žemyn šriftu. Tiriamasis tekstą laikė 40 centimetrų atstumu nuo akių ir skaite be akinių. Normalus teksto skaitymo šriftas yra 12 (pirma lentelès eilutè). Iš viso lentelèje buvo 9 eilutès su tekstu nuo 12 iki 20 šrifto. Testavimas buvo registruojamas matomo šrifto už-

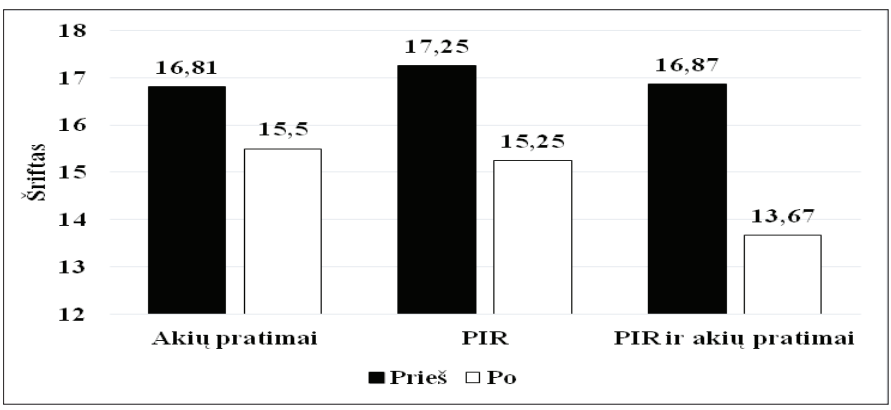

1 pav. Toliaregių abiejų akių regos pokyčiai vertinant skirtingas metodikas - (rezultatai prieš ir po tyrimo). PIR - postizometrinè relaksacija

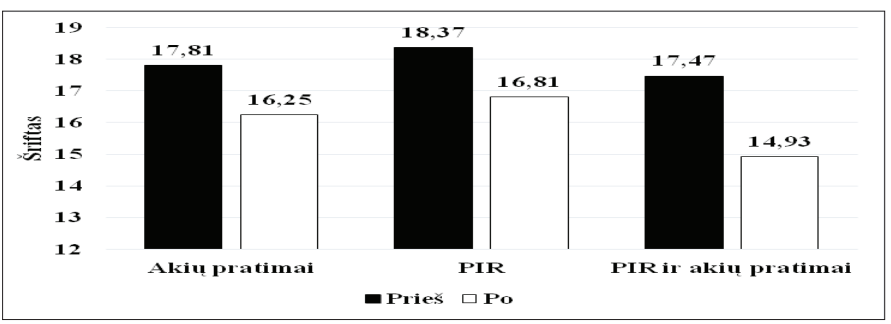

2 pav. Toliaregių kairès akies regos pokyčiai vertinant skirtingas metodikas - (rezultatai prieš ir po tyrimo). PIR - postizometrinè relaksacija

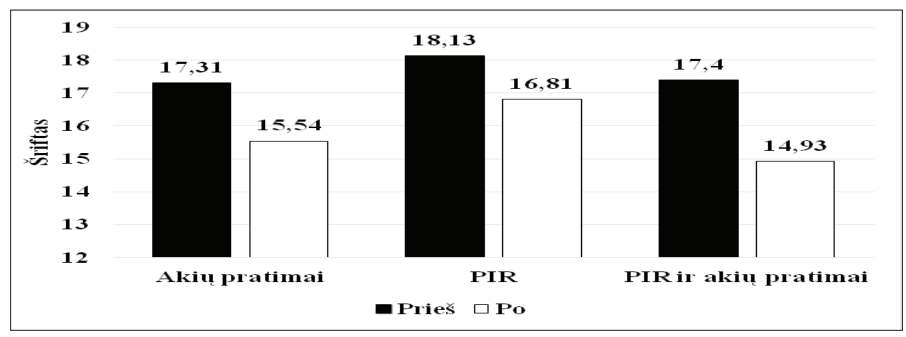

3 pav. Toliaregių dešinės akies regos pokyčiai vertinant skirtingas metodikas - (rezultatai prieš ir po tyrimo). PIR - postizometrinè relaksacija

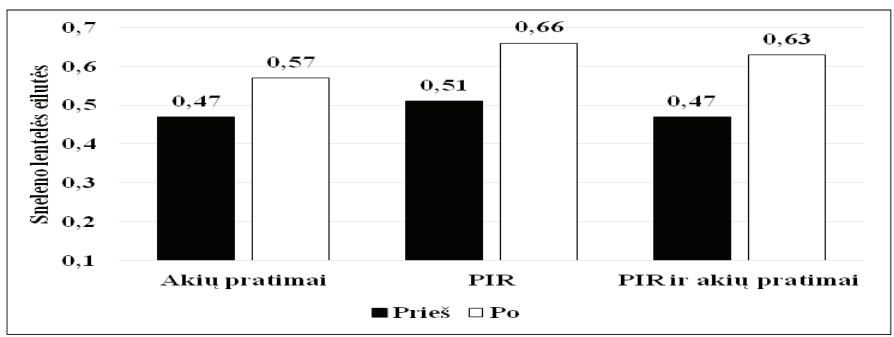

4 pav. Trumparegių kairès akies regos pokyčiai vertinant skirtingas metodikas - (rezultatai prieš ir po tyrimo). PIR - postizometrinè relaksacija 
fiksavimu testavimo lentelèje. Jei teksto skaitymo lentelèje perskaitomas šriftas buvo didesnis už 12, buvo nustatomas toliaregystès sutrikimas.

Visi tiriamieji buvo suskirstyti $i$ tris grupes. I grupès tiriamieji: trumparegiai $(n=15)$ ir toliaregiai $(n=15)-10$ dienų atliko akių pratimus, II grupès tiriamiesiems: trumparegiams $(n=15)$ ir toliaregiams $(n=15)-10$ dienų taikyta postizometrinè relaksacija, III grupès tiriamiesiems: trumparegiams $(n=15)$ ir toliaregiams $(n=15)-10$ dienų taikyta postizometrinè relaksacija kartu su akių pratimais. Regèjimo atstatymo programa taikyta kasdien, iš viso 10 dienų. Taikytas statistinis duomenų apdorojimas. Tyrimas atliktas laikantis etikos principų.

Akiu pratimų programa parengta pagal Beitso metodą regejimui pagerinti be akinių [5], siekta sustiprinti nusilpusius akių raumenis ir atpalaiduoti įtemptus akių raumenis. Kiekvienas pratimas atliekamas nuo 8 iki 12 kartu.

Tiriamiesiems buvo taikoma postizometrinè relaksacija (izometrinis raumens ittempimas ir po jo sekantis pasyvus raumens ištempimas) kaklo ir pečių juostos raumenims, kuriuose buvo jaučiamas raumenų tonuso padidejjimas, ịtampa. Postizometrinè relaksacija tiriamiesiems pradžioje buvo atliekama gulint ant nugaros, vèliau sédimoje padètyje.

Statistinè tyrimo duomenų analizè atlikta SPSS 20.0 programa. Grafinis rezultatu vaizdavimas atliktas Excel 2010 programa. Nepriklausomų kintamujų vidurkių tarpusavio skirtumų statistinio reikšmingumo palyginimui naudotas Independent Sample (nepriklausomų kintamųjų) T testas. Požymių ryšio stiprumui vertinti skaičiuotas Pearson'o koreliacijos koeficientas (r). Jei $0<|\mathrm{r}| \leq 0,25$, dydžių tarpusavio priklausomybė yra silpna, jei $0,3<|\mathrm{r}| \leq 0,6$, dydžių tarpusavio priklausomybe் - vidutiniška, jei $0,6<|\mathrm{r}| \leq 1$, dydžių tarpusavio priklausomybè - stipri. Kai reikšmingumo lygmuo $\mathrm{p} \leq 0,05$, požymių skirtumas tiriamujju grupėse laikytas statistiškai reikšmingas.

\section{Tyrimo rezultatai ir jų aptarimas}

Toliaregiams pritaikius PIR kartu su akių pratimais po 10 procedūrų pastebèta abiejų akių regos gerẻjimo ten-

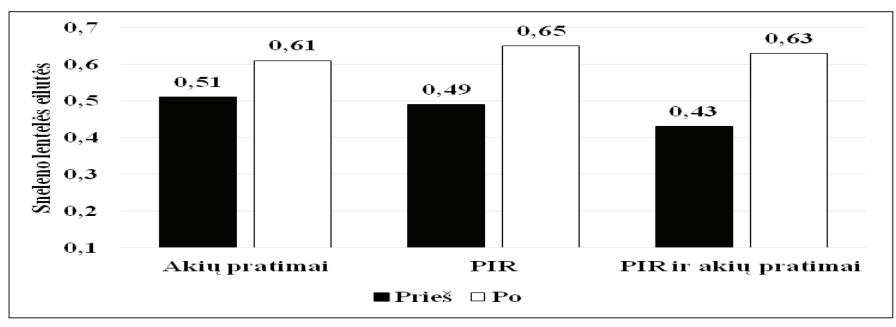

5 pav. Trumparegių dešinės akies regos pokyčiai vertinant skirtingas metodikas - (rezultatai prieš ir po tyrimo). PIR - postizometrinè relaksacija dencija, skaitomo teksto šrifto pokytis nuo $16,87 \pm 1,96$ iki $13,67 \pm 1,29$. Taikant atskirai tik PIR, stebèta regos gerejjimo tendencija, skaitomo teksto šrifto pokytis nuo $17,25 \pm 1,99$ iki $15,25 \pm 2,02$. Taikant atskirai tik akių pratimus,--skaitomo teksto šrifto pokytis nuo $16,81 \pm 1,66$ iki $15,5 \pm 1,87$ (1 pav.).

PIR kartu su akių pratimais poveikis abiem akims yra reikšmingai didesnis nei naudojant PIR atskirai $(p=0,003$, $\mathrm{p}<0,05$ ). PIR kartu su akių pratimais poveikis taip pat yra statistiškai reikšmingai didesnis nei vien tik akių pratimų poveikis abiem akims $(p=0,000, p<0,05)$. Taip pat naudojant PIR metodą atskirai, poveikis yra geresnis nei tik atliekant akių pratimus $(\mathrm{p}=0,019, \mathrm{p}<0,05)$.

Toliaregiams pritaikius PIR kartu su akių pratimais, po 10 procedūrų pastebèta kairès akies gerèjimo ten-

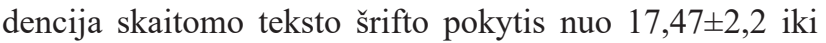
$14,93 \pm 2,08$. Taikant PIR atskirai, pastebèta kairès akies regos gerejimo tendencija, skaitomo teksto šrifto pokytis nuo $18,37 \pm 2,02$ iki $16,81 \pm 2,00$. Taikant atskirai tik akių pratimus, skaitomo teksto šrifto pokytis - nuo $17,81 \pm 1,89$ iki 16,25 $\pm 1,59$ (2 pav.).

PIR kartu su akių pratimais poveikis yra statistiškai reikšmingai didesnis nei naudojant PIR atskirai $(\mathrm{p}=0,007$, $\mathrm{p}<0,05$ ). PIR kartu su akių pratimais poveikis yra taip pat statistiškai reikšmingai didesnis nei vien tik akių pratimų poveikis kairiajai akiai $(\mathrm{p}=0,014, \mathrm{p}<0,05)$. Tiek naudojant atskirai PIR metodą, tiek ir akių pratimus kairiajai akiai, poveikis yra teigiamas, bet visiškai nesiskiria $(\mathrm{p}=1, \mathrm{p}>0,05)$.

Toliaregiams pritaikius PIR kartu su akių pratimais, po 10 procedūrų pastebèta dešinès akies gerèjimo ten-

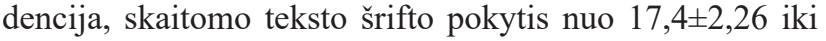
$14,93 \pm 1,98$. Taikant PIR atskirai, pastebèta dešinès akies regos gerejimo tendencija: skaitomo teksto šrifto pokytis nuo $18,13 \pm 2,16$ iki $16,81 \pm 2,17$. Taikant tik akiu pratimus, skaitomo teksto šrifto pokytis - nuo $17,31 \pm 1,68$ iki 15,54 $\pm 1,45$ (3 pav.).

PIR kartu su akių pratimais poveikis yra statistiškai reikšmingai didesnis nei naudojant PIR atskirai $(\mathrm{p}=0,016$, $\mathrm{p}<0,05$ ). PIR kartu su akiu pratimais poveikis yra taip pat statistiškai reikšmingai didesnis negu vien tik akių pratimų poveikis dešiniajai akiai $(\mathrm{p}=0.001, \mathrm{p}<0.05)$. Tiek naudojant atskirai PIR metodą, tiek akiu pratimus dešiniajai akiai, jų poveikio efektyvumas, lyginant vidurkius, atrodo skirtingai, tačiau statistiškai tai nereikšmingas skirtumas $(\mathrm{p}=0,452, \mathrm{p}>0,05)$.

Lygindami visu metodiku poveiki toliaregiu tiriamųjų kairei, dešinei bei abiem akims, galima teigti, kad PIR kartu su akių pratimais yra veiksmingesné regèjimo gerinimo metodika negu atskirai PIR ar akių pratimai. Skirtumo tarp PIR ir akiu pratimų poveikio kairès ir dešinès akies regai nèra, tačiau PIR metodika 
yra veiksmingiau pagerino regèjimą abiejomis akimis.

Trumparegiams pritaikius PIR kartu su akių pratimais, po 10 procedūrų pastebėta abiejų akių regos gerejjimo tendencija nuo $0,51 \pm 0,29$ iki $0,73 \pm 0,24$, vertinant pagal Sneleno lentelę. Taikant PIR atskirai stebima regos gerejjimo tendencija nuo $0,58 \pm 0,29$ iki $0,71 \pm 0,24$. Taikant tik akiu pratimus rezultatas pagerèjo- nuo $0,6 \pm 0,3$ iki $0,71 \pm 0,26$ (4 pav.). Nors visos metodikos suteikia teigiamą poveiki regèjimo gerinimui, tačiau statistiškai regejjimo pokyčiai reikšmingai nesiskiria $(\mathrm{p}>0,05)$.

Trumparegiams taikant PIR kartu su akių pratimais, po 10 procedūrų pastebèta kairès akies regos gerejjimo tenden-

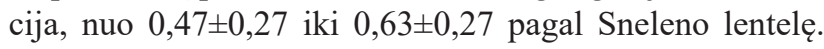
Taikant PIR atskirai, stebèta kairès akies regos gerejjimo tendencija nuo $0,51 \pm 0,27$ iki $0,66 \pm 0,27$ pagal Sneleno lentelę. Taikant tik akių pratimus, rega pagerejo - nuo $0,47 \pm 0,27$ iki $0,57 \pm 0,25$ (4 pav.).

PIR kartu su akių pratimais metodo poveikis kairès akies regai yra statistiškai reikšmingas lyginant su akių pratimų poveikiu ( $\mathrm{p}=0,032, \mathrm{p}<0,05)$. PIR kartu su akių pratimais ir atskirai PIR poveikio rezultatai statistiškai nesiskiria $(\mathrm{p}=0.954, \mathrm{p}>0.05)$. Statistiškai reikšmingo skirtumo tarp akių pratimų poveikio ir atskirai PIR poveikio kairès akies regai nèra, nes $(=0,151, \mathrm{p}>0,05)$

Trumparegiams pritaikius PIR kartu su akiu pratimais, po 10 procedūrų pastebèta dešinès akies gerẻjimo tendencija nuo $0,43 \pm 0,25$ iki $0,63 \pm 0,26$. Taikant PIR metodą atskirai, pastebèta dešinès akies regos gerèjimo tendencija nuo $0,49 \pm 0,25$ iki $0,65 \pm 0,26$. Taikant tik akių pratimus, regos pokyčio skirtumas nuo $0,51 \pm 0,28$ iki $0,61 \pm 0,27$ (5 pav.).

PIR kartu su akių pratimais poveikis dešinès akies regai yra statistiškai reikšmingas, lyginant su akių pratimais $(\mathrm{p}=0,025, \mathrm{p}<0,05)$. PIR kartu su akių pratimais ir atskirai PIR poveikio rezultatai statistiškai nesiskiria $(\mathrm{p}=0.589$, $\mathrm{p}>0.05)$. Statsitiškai reikšmingo skirtumo tarp akių pratimu ir atskirai PIR metodikos taikymo nèra, nes $p=0,165, p>0,05$.

Apibendrinant galima teigti, kad toliaregiu ir trumparegių rega pagerejo, taikant visas metodikas. Akių pratimai turejjo teigiamą, bet statistiškai nereikšmingą poveiki toliaregių ir trumparegių regejjimui. Naujosios Zelandijos Kraistčerčo universiteto ir ligoninès specialistai atliko 43 tyrimus, skirtus akių pratimų apžvalgai, rezultatai irgi buvo staistiškai nereikšmingi [14] Mes patvirtinome teigiamą kaklo ir pečiu juostos postizometrinès relaksacijos, taikomos kartu su akių pratimais, poveikị toliaregių ir trumparegių regejjimui. Atlikti tyrimai [15] irgi patvirtino ryšs tarp kaklo būklès ir regos. Derinant akių mankštą su kaklo masažu, greičiau ir efektyviau pasiekiami teigiami regejjimo pokyčiai pagerinant regèjimą [4]. Teigiamą postizometrinès relaksacijos poveikị trumapregiams, prilygstantị posti- zometrinès relaksacijos, taikomos kartu su akių pratimais, poveikiui, galima aiškinti tuo, kad kaklinès stuburo dalies linkis, raumenu spazmai ir ịtampa yra viena iš trumparegystès priežasčių [6]

\section{Išvados}

1. Kaklo ir pečių juostos postizometrinè relaksacija, taikoma kartu su akių pratimais, pagerino toliaregiu ir trumparegių regèjimą $(p<0,05)$.

2. Kaklo ir pečių juostos postizometrinè relaksacija efektyviai gerina trumparegiu regèjimą. Postizometrinès relaksacijos kartu su akiu pratimais ir atskirai postizometrinès relaksacijos poveikio rezultatai statistiškai nesiskiria $(\mathrm{p}=0.589, \mathrm{p}>0.05)$.

3. Akių pratimai turèjo teigiamą, bet statistiškai nereikšmingą poveiki toliaregių ir trumparegių regejimui $(\mathrm{p}>0,05)$.

\section{Literatūra}

1. Troickaja S. Atsikratykite akinių žudiku visiems laikams! Klaipèda: Leidykla „Logitema“, 2008.

2. Ostermeier-Sitkowski U. Akių pratimai dirbantiems kompiuteriu. AB „Spauda“, 2005; 30.

3. Proškuvienè R. Mūsų vaikų akys. Vilniaus pedagoginis universitetas, Sveikatos ugdymo katedra, 2010; [žiūrèta 2016, kovo 26 d.]. Prieiga per Internetą: <http://www.ikimokyklinis.lt/ index.php/straipsniai/specialistams/musu-vaiku-akys/5407>

4. Finkelšteinaitė J., Valužienė N.K., Damanskas J. Masažas. Vilnius, Avicena, 2008.

5. Bates W.H. Beitso metodas regejjimui pagerinti be akiniu. Šiauliai, A.S. Narbuto leidykla, 1996.

6. Schafer RC. Clinical Biomechanics. Musculoskeletal actions and reactions: Lippincott Williams and Wilkins, second edition, 1996.

7. Tacas S. Kūno derinimas: malonus gyvenimas be vaistų. Mažoji leidykla. Vilnius, 2014.

8. Vazquez-Delgado E, Cascos-Romero J, Gay-Escoda C. Miofascial pain associated to trigger points: a literature review. (I): Epidemiology, clinical treatment and etiopathogeny. Oral medicine and pathology 2009; 14(10): $494-8$.

https://doi.org/10.4317/medoral.14.e494

9. Plowman SA. Physical activity, physical fitness, and low back pain. Exerc Sport Sci 1992; 20: 221 - 242.

10. Norbekovas M. Kvailio patirtis, arba kelias i praregèjimą. Kaip atsikratyti akinių. Vilnius. Alma littera, 2014.

11. Girskis J. Apie žmogaus ir visuomenès stuburą. Vilnius. Tyto alba, 2011.

12. Emary P. Use of post-isometric relaxation in the chiropractic management of a 55-year-old man with cervical radiculopathy. Journal of the Canadian Chiropractic Association 2012; 56(1):9-17. 
13. Harris JK, Emptage NP, Lum MF. Visual training for refractive errors. Journal of the American Acedemy of Ophthalmology 2013.

14. Rawstron JA, Burley CD, Elder MJ. A systematic review of the applicability and efficacy of eye exercises. Journal of Pediatric Ophthalmology and Strabismus 2005; 42(2):82-8.

15. Marumoto T, Sotoyama M, Villanueva MB, Jonai H, Yamada H, Kanai A, Saito S. Correlation analysis between visual acuity and sitting postural parameters of young students. Department of Ophthalmology, Juntendo University School of Medicine, Japan. [žiūrèta 2016 m. balandžio 27 d.]. Prieiga per Internetą: $<$ http://www.ncbi.nlm.nih.gov/pubmed/9170844>

\section{IMPACT OF NECK-RELEASE AND EYE EXERCISES FOR EYESIGHT}

\section{T. Miklius, A. Razbadauskas, J. Sučylaitė}

Key words: cervical spine, postisometric relaxation, nearsighted, farsighted, visual improvement, eye exercises.

Summary

Research aim - to evaluate the effect of neck relaxation and ocular exercises on seeing. Survey was done January - April months of 2016.90 people voluntarily participated in the study, 45 of them were near-sighted and other 45 were farsighted. Research entities were divided into three groups, each of group had two subgroups:
I group near-sighted $(n=15)$ and far - sighted $(n=15)$ had eye exercises, II group near-sighted $(n=15)$ and far- sighted $(n=15)$ had postisometric relaxation, III group near-sighted $(n=15)$ and far- sighted $(n=15)$ had post isometric relaxation and eye exercises together. For the selection of research participants and for evaluation of quality of seeing of near-sighted visual acuity table (Selens) was used, text reading table was used for far-sighted. Visual strengthening programme was applied daily, for 10 days in a row. Statistical data processing and analysis were applied. This research was done in accordance with the ethics. Research results have showed, that in the end of eye strenghtening programme that visual improvement was found in all groups. Significant improvement was found in a group, which had postisometric relaxation and ocular exercises together. Postisometric neck and shoulder relaxation effectively improve myopia eyesight. The efect of method of postisometric relaxation combined with eye exercises and the efect postisometric relaxation separately statistically do not $\operatorname{differ}(\mathrm{P}=0.589, \mathrm{P}>0.05)$ . Eye exercises had a positive but statistically insignificant effects on hyperopia and myopia eyesight ( $\mathrm{p}>0.05)$.

Correspondence to: jurate.sucylaite@ku.lt

Gauta 2016-11-16 